\title{
Hepatitis C Virus Related Liver Dysfunction During Chemotherapy for Hodgkin's Lymphoma
}

\author{
Serpil EROL ${ }^{1}$, Ayten KADANALI ${ }^{1}$, Zulal OZKURT ${ }^{1}$, Ihami KIKI ${ }^{2}$, Mehmet PARLAK ${ }^{1}$ \\ ${ }^{1}$ Ataturk University Facultuy of Medicine, Department of Infectious Diseases and Clinical Microbiology, \\ ${ }^{2}$ Ataturk University Facultuy of Medicine, Department of Internal Medicine, Erzurum, TURKEY
}

\begin{abstract}
Concurrent Hodgkin's lymphoma and Hepatitis C virus (HCV) infection is a rare clinical condition. Also, HCV related liver dysfunction during lymphoma chemotherapy is uncommon and most data come from patients with non-Hodgkin's lymphoma. We reported here a case of HCV related liver dysfunction during chemotherapy for Hodgkin's lymphoma and long term follow-up results of the patient, and we reviewed the literature.
\end{abstract}

Keywords: Hepatitis C, Infection, Liver dysfunction, Lymphoma

ÖZET

Hodgkin Lenfoma Kemoterapisi Sırasında Ortaya Çıkan Hepatit C Virusu ile ilişskili Karaciğer Disfonksiyonu

Hodgkin lenfoma ve Hepatitis C virus (HCV) infeksiyonu birlikteliği nadir bir klinik durumdur. Ayrıca, lenfoma kemoterapisi esnasında ortaya çıkan HCV reaktivasyonu da sık karşılaşılmayan bir durum olup, bu konudaki verilerin çoğu da non-Hodgkin lenfoma॥ hastalardan gelmektedir. Biz burada Hodgkin lenfoma kemoterapisi sırasında ortaya çıkan HCV'ye bağlı bir karaciğer disfonksiyonu olgusunu, bu olgunun uzun süreli sonuçlarını sunduk ve bu konudaki literatürü irdeledik

Anahtar Kelimeler: Hepatit C, İnfeksiyon, Karaciğer disfonksiyonu, Lenfoma 


\section{INTRODUCTION}

Several studies have reported higher prevalence of hepatitis $\mathrm{C}$ virus (HCV) infection among patients with non-Hodgkin's lymphoma (NHL) than general population..$^{1,2}$ However, an association of $\mathrm{HCV}$ with Hodgkin's lymphoma is not clear. ${ }^{2-4}$

As many chemotherapeutic agents are hepatotoxic, treatment of HCV-positive lymphoma patients is a challenge. However, a major issue that has to be considered is the effect of commonly used chemotherapeutics, i.e. corticosteroids, rituiximab, cytotoxic drugs, on the course of HCV infection. Data on the consequence of chemotherapy on the course of $\mathrm{HCV}$ infection in those patients have been controversial, and most of them are related to NHL.-11 Owing to the rare concurrence of $\mathrm{HCV}$ infection and Hodgkin's lymphoma, there are scarce published data on the effects of chemotherapy regimens on the course of HCV infection. ${ }^{5,9}$ Furthermore, treatment and long term follow-up data of $\mathrm{HCV}$ infection in such patients are unavailable.

We report here a case of $\mathrm{HCV}$ related liver dysfunction during chemotherapy for Hodgkin's lymphoma, and its successful treatment with long term follow-up results, despite the recurrence of lymphoma and subsequent chemotherapies.

\section{CASE REPORT}

A 23-years-old woman was referred to infectious disease department in October 2007 with the diagnosis of hepatitis $\mathrm{C}$ infection. She had a history of Hodgkin's lymphoma (noduler sclerosing type, stage IV B) diagnosed 1 year ago, and five courses of chemotherapy with intravenous ABVD regimen (adriamycin $25 \mathrm{mg} / \mathrm{m}^{2}$, bleomycin $10 \mathrm{mg} / \mathrm{m}^{2}$, vincristine $1.4 \mathrm{mg} / \mathrm{m}^{2}$, dacarbazine $375 \mathrm{mg} / \mathrm{m}^{2}$ ). The courses were given at 4-week intervals. During the 5th course, the patient had developed jaundice and severe fatigue. Laboratory tests revealed HCV infection.

Physical examination on admision revealed jaundice, hepatomegaly $2 \mathrm{~cm}$ below the costal margin, and splenomegaly $3 \mathrm{~cm}$ below the costal margin. Laboratory findings were as follows: White blood cell count: $7100 / \mathrm{mm}^{3}$, hemoglobin: $14.3 \mathrm{~g} / \mathrm{dL}$, platelet count: $226000 / \mathrm{mm}^{3}$, alanine aminotransferase (ALT): 1413 IU/L, aspartate aminotransferase
(AST) $1220 \mathrm{IU} / \mathrm{L}$, total bilirubin $12.3 \mathrm{mg} / \mathrm{dL}$, direct bilurubin $6.1 \mathrm{mg} / \mathrm{dL}$, prothrombin time (PT): 14 sec, international normalised ratio (INR): 1.05, gamma-glutamyl transpeptidase (GGT): $187 \mathrm{U} / \mathrm{L}$. Anti-HCV antibody was positive and hepatitis B virus (HBV) markers were negative by ELISA method. Serum HCV-RNA level was 1.000 .000 copy $/ \mathrm{mL}$ by a real time polymerase chain reaction (RT-PCR) method. HCV genotype was not specified. The patient had no history of blood transfusion, intravenous drug use and alcohol abuse. ALT, AST and bilurubin levels returned to normal within 20 days without any specific treatment. Because there was uncertainty about the diagnosis (acute HCV infection or chemotherapy related reactivation of chronic $\mathrm{HCV}$ ), the patient underwent a liver biopsy confirming a histopathologic diagnosis of chronic viral hepatitis. Liver biopsy indicated moderate inflammation (Knodell score 6) and stage 1 fibrosis. Treatment with Peg-IFN- $\alpha 2 a$ (180 $\mu$ g standard dose) per week and ribavirin $1000 \mathrm{mg} /$ day was initiated in January 2008.

At the 4th week of treatment ALT level was normal and HCV-RNA was negative (early virological response). HCV-RNA negativity continued at 12 and 24th weeks of the treatment. By the end of the 24th week, the treatment was discontinued due to patient's intolerance (severe fatigue and depression). The patient remained in remission during HCV treatment and received no further chemotherapy for lymphoma. Unfortunately, three months after discontinuation of HCV treatment, lymphoma recurred. The patient was treated with 3 courses of ICE (ifosfamide, carboplatin and etoposide) protocol. Because the patient had incomplete response to ICE, autologous stem cell transplantation was planned. But the patient declined transplantation. Her disease progressed with pulmonary and multiple lymph node involvement in subsequent period. Three months after the last course of ICE treatment, the patient received another chemotherapy with ESHAP (etoposide, methylprednisolone, high-dose cytarabine and cisplatin). During the ICE chemotherapy and subsequent 6 months (18 months after completion of $\mathrm{HCV}$ treatment), the patient did not experience any recurrence of the HCV infection. 


\section{DISCUSSION}

There are limited number of studies about HCV infection in patients with Hodgkin's lymphoma. ${ }^{2-5,9}$ Also, there are only two case reports in the literature that evaluate the effect of chemotherapy for Hodgkin's lymphoma on concurrent HCV infection. ${ }^{59}$ In the first report, Vento et al. ${ }^{5}$ described a patient receiving ABVD chemotherapy for Hodgkin's disease. At the end of chemotherapy, serum HCVRNA level was very high $\left(10^{8} \mathrm{copy} / \mathrm{mL}\right)$. Twenty four days after stopping the chemotherapy, the patient developed fulminant hepatitis with decline in viremia $\left(10^{2}\right.$ copy $\left./ \mathrm{mL}\right)$. However, the patient recovered with supportive therapy. In the second case, ABVD chemotherapy caused only asymptomatic transient increase in viremia and transaminases. These two reports focused on the effect of chemotherapy on HCV replication. The authors had not mentioned the course and treatment of the infection. To our knowledge, our case is the second report of ABVD related $\mathrm{HCV}$ liver dysfunction during Hodgkin's lymphoma chemotherapy in English literature. Also, this is the first report of HCV treatment in a patient with Hodgkin's lymphoma.

It is accepted that chemotherapy related liver dysfunction occurs at a lower incidence in HCVpositive patients than in $\mathrm{HBV}$-positive patients. ${ }^{7,8,12}$ However, 7-30\% of the HCV-positive lymphoma patients experience $\mathrm{HCV}$ related hepatotoxicity secondary to chemotherapy. ${ }^{6}$ In a study, liver enzyme abnormalities during chemotherapy for malignancies were seen in $54 \%$ of the HCV-positive patients, and in $34 \%$ of the HCV-negative patients. ${ }^{7}$ Chemotherapy was not associated with jaundice, fulminant hepatitis or death in those with HCV infection.

$\mathrm{HCV}$-related liver dysfunction generally occurs a few months after the cessation of immunosuppressive therapy. ${ }^{5-7,12}$ In contrast, in our patient, liver enzyme abnormalities was noted during the chemotherapy period and this implied to us drug related hepatotoxicity. However, liver biopsy and virological tests indicated HCV-related liver injury.

Most hepatitis $\mathrm{C}$ exacerbation cases have been reported to be linked to the use of corticosteroid and rituximab containing chemotherapy. ${ }^{11-14}$ Reports on hepatitis $\mathrm{C}$ exacerbation related to the use of ABVD regimen, as in our case, are scarce. ${ }^{5}$ Presence of active hepatitis, HBV coinfection and corti- costeroid treatment are defined as risk factors for HCV-related liver injury. ${ }^{6}$

The standard treatment for chronic hepatitis $\mathrm{C}$ is the combined use of pegylated interferon-alpha (PegIFN- $\alpha$ ) and ribavirin for 48 weeks in viral genotype 1 , and 24 weeks in genotype 2 and $3 .{ }^{15}$ Optimal $\mathrm{HCV}$ treatment is not clear in patients with lymphoma. Data is limited and most are concerned with non-Hodgkin's lymphoma. Although viral genotype was unknown in our case, HCV treatment was discontinued at the end of 24th week because of patient's intolerance. Nevertheless, the patient achieved sustained virological response (SVR), defined as undetectable HCV-RNA 24 weeks after the end of treatment.

Although it is a rare event, recurrence of HCV infection in a sustained responder may be probable after immunosuppressive therapy. ${ }^{11,13}$ Lin et al. ${ }^{11}$ reported two cases of hepatitis $\mathrm{C}$ who achieved SVR and relapsed after treatment with immunosuppressive therapy. Thomopoulos et al. ${ }^{13}$ reported a patient infected with genotype 3 who achieved SVR after combination treatment with peg-IFN- $\alpha$ and ribavirin for 6 months. Sixteen months later, non-Hodgkin's lymphoma was diagnosed. After successful completion of chemotherapy for lymphoma, the patient presented with recurrent $\mathrm{HCV}$ infection with the same genotype. It is interesting that in spite of short term HCV treatment, recurrence of primary disease and repeated chemotherapy, our patient did not experience any recurrence of $\mathrm{HCV}$ infection.

In conclusion, our case shows the need for awareness of reactivation of $\mathrm{HCV}$ infection in patients receiving chemotherapy for haematological malignancies. As well as HBV infection, all canditates for chemotherapy or immunosuppressive therapy should be secreened for HCV infection. HCV positive patients who receive chemotherapy or immunosuppressive therapy should be followed carefully by means of ALT and HCV RNA. In case of HCV related liver dysfunction, antiviral treatment should be started early. Currently, there is no conflicting evidence for preemptive treatment of $\mathrm{HCV}$ infection in those patients. 


\section{REFERENCES}

1. Mele A, Pulsoni A, Bianco E, et al. Hepatitis C virus and B-cell non-Hodgkin lymphomas: an Italian multicenter case-control study. Blood 102: 996-999, 2003.

2. Schöllkopf C, Smedby KE, Hjalgrim H, et al. Hepatitis $\mathrm{C}$ infection and risk of malignant lymphoma. Int $\mathrm{J}$ Cancer 122: 1885-1890, 2008.

3. Bianco E, Marcucci F, Mele A, et al. Italian Multi-Center case-control study. Prevalence of hepatitis $C$ virus infection in lymphoproliferative diseases other than Bcell non-Hodgkin's lymphoma, and in myeloproliferative diseases: an Italian Multi-Center case-control study. Haematologica 89: 70-76, 2004.

4. Wiwanitkit W. Summary on the seroprevalence of hepatitis C among patients with Hodgkin's Iymphoma, an implication for risk by metanalysis. Shiraz E-Medical Journal 2007. http://semj.sums.ac.ir/vol8/jan2007/ hcv.htm (access date 17.6.2011).

5. Vento S, Cainelli F, Mirandola F, et al. Fulminant hepatitis on withdrawal of chemotherapy in carriers of hepatitis C virus. Lancet 347: 92-93, 1996.

6. Dizdar O, Tapan $\cup$, Aksoy $S$, et al. Liver dysfunction after chemotherapy in lymphoma patients infected with hepatitis C. Eur J Haematology 80: 381-385, 2008.

7. Zuckerman E, Zuckerman T, Douer D, et al. Liver dysfunction in patients infected with hepatitis $C$ virus undergoing chemotherapy for hematologic malignancies. Cancer 83: 1224-1230, 1998.

8. Markovic S, Drozina G, Vovk M, Fidler-Jenko M. Reactivation of hepatitis $B$ but not hepatitis $C$ in patients with malignant lymphoma and immunosuppressive therapy. A prospective study in 305 patients. Hepatogastroenterology 46: 2925-2930, 1999.

9. Pejsa V, Grgurevic U, Kujundzic M, et al. No adverse effect of ABVD chemotherapy in a patient with chronic hepatitis $\mathrm{C}$ and Hodgkin's disease. Wien Clin Wochenschr 116: 695-697, 2004.

10. Melisko ME, Fox R, Venook A. Reactivation of hepatitis $C$ virus after chemotherapy for colon cancer. Clin Oncol (R Coll Radiol) 16:204-205, 2004.

11. Lin A, Thadareddy A, Goldstein MJ, Lake-Bakaar G. Immune suppression leading to hepatitis $\mathrm{C}$ virus reemergence after sustained virological response. J Med Virol 80: 1720-1722, 2008.
12. Kawatani $T$, Suou $T$, Tajima $F$, et al. Incidence of hepatitis virus infection and severe liver dysfunction in patients receiving chemotherapy for hematologic malignancies. Eur J Haematol 67: 45-50, 2001.

13. Thomopoulos K, Giannakoulas NC, Tsamandas AC, et al. Recurrence of HCV infection in a sustained responder after chemotherapy for non-Hodgkin's lymphoma: successful retreatment. Am J Med Sci; 336: 73-76, 2008.

14. Aksoy S, Abali H, Kilickap S, et al. Accelerated hepatitis $C$ virus replication with rituximab treatment in a nonHodgkin's lymphoma patient. Clin Lab Haematol 28: 211-214, 2006.

15. Ghani MG, Strader DB, Thomas DL, Seef LB. Diagnosis, management and treatment of hepatitis C: An update (American Association for the Study of Liver Diseases' Guideline). Hepatology 49: 1335-1374, 2009.

\section{Correspondence}

Dr. Serpil EROL

Atatürk Üniversitesi Tıp Fakültesi

Enfeksiyon Hastalıkları ve Klinik Mikrobiyoloji Anabilim Dalı

Aziziye Hastanesi

25100 Erzurum / TURKEY

Tel: (+90.442) 3166333

Fax : (+90.442) 3166340

e-mail: sererol@gmail.com 